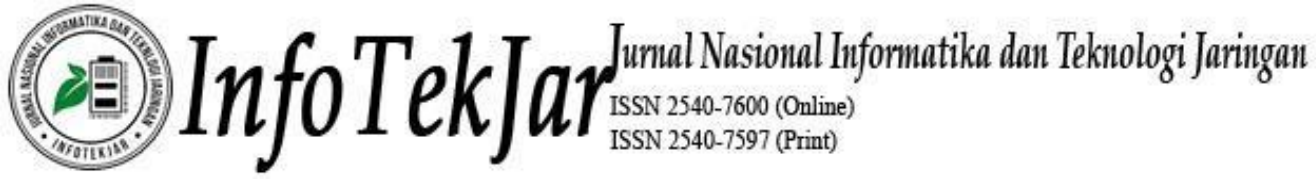

\section{PERANCANGAN APLIKASI PENJUALAN TIKET KAPAL MENGGUNAKAN NEAR FIELD COMMUNICATION (NFC) PADA PERANGKAT BERGERAK}

\author{
Dwi Ely Kurniawan*, Agus Fatulloh, Nur Cahyono Kushardianto \\ 1,2,3 Teknik Informatika, Politeknik Negeri Batam \\ Jl. Ahmad Yani, Batam Center, Batam, Kepulauan Riau 29461 \\ *Email:dwialikhs@polibatam.ac.id
}

\begin{abstract}
Abstrak - Kepulauan Riau merupakan wilayah yang berupa pulau-pulau kecil dimana transportasi yang digunakan sebagian besar menggunakan kapal. Pemesanan tiket kapal saat ini masih menggunakan cara konvensional, dimana para penumpang membeli tiket di loket kemudian membayar langsung ke petugas dan mendapatkan bukti pembelian berupa tiket dan tiket tersebut di pegang oleh masing-masing penumpang selama perjalanan menggunakan kapal. Pengarsipan dalam penjualan tiket masih menggunakan buku, kertas dan alat tulis, hal ini tentu tidak praktis dalam mengolah data. Pada penjualan tiketpun sulit dapat diketahui jumlah penjualan tiket yang terjual. Penelitian ini mencoba membuat suatu prototipe perancangan sistem penjualan tiket kapal menggunakan perangkat NFC. Perangkat NFC merupakan perangkat komunikasi dengan teknologi berbasis konektivitas nirkabel berbasis RFID ( Radio Frequency Identification ). RFID menggunakan induksi medan magnet untuk memungkinkan komunikasi antar perangkat elektronik dalam jarak yang dekat. Perancangan sistem akan memanfaatkan e-KTP (Kartu Tanda Penduduk elektronik). Hasil perancangan berupa prototipe aplikasi pada sisi client dan sisi server. Sisi client pada perangkat mobile menggunakan sistem operasi android dan sisi server menggunakan aplilkasi web untuk menyimpan data transaksi penjualan tiket sehingga diharapkan dapat mengotomatisasi data transaksi penjualan tiket.
\end{abstract}

Keywords - penjualan, tiket kapal, nfc.

\section{PENDAhuluan}

Teknologi Near Field Communication (NFC) merupakan teknologi yang saat ini telah mendukung di beberapa perangkat bergerak / smartphone. Teknologi ini banyak diimplementasikan untuk membuka aplikasi secara otomatis, memberi tahu posisi suatu tempat, menjalankan tugas tertentu dan melakukan pembayaran [8].

Pengguna smartphone menurut data sekitar 65.2 juta pengguna sedangkan jumlah penduduk Indonesia mencapai 250 juta jiwa [3]. Artinya hampir $30 \%$ pengguna smartphone di Indonesia, sehingga dengan mengintegrasikan aplikasi tiket kapal dengan perangkat smartphone menjadi lebih baik dan akurat. Aplikasi Penjualan Tiket Kapal berbasis NFC ini bertujuan untuk mempermudah dalam pemindahan data transaksi penjualan tiket, serta melakukan otomatisasi proses dalam validasi tiket dan pencatatan data penjualan tiket lebih akurat.

Teknologi NFC telah banyak diimplementasikan dan diintegrasikan dengan perangkat mobile phone. Hampir tidak diragukan lagi bahwa kini telah banyak perangkat mobile phone yang telah diciptakan telah ditambahkan perangakat NFC. Lebih dari 150 juta pengguna mobile phone sudah dilengkapi dengan NFC di tahun 2014 [2]. Beberapa penelitian yang telah dikembangkan dan banyak dijabarkan [6] seperti pada penggunaan RFID pada pembayaran tiket bus [1], penggunaan NFC pada tiket bus [2], pemakaian NFC pada mobile kupon [5], pembayaran mobile kartu kredit untuk barang dan layanan dengan menggunakan NFC [8], NFC
Smart Tourist Card dengan mobile Android [9], teknologi pintu rumah NFC [10], dan lain sebagainya. Pada penelitian ini penggunaan teknologi NFC diimplementasikan pada tiket kapal dengan bantuan e-KTP sebagai media transaksi. Data saldo disimpan pada e-KTP tersebut. Hal ini diharapkan dapat mendukung kebutuhan transportasi utama kapal yang sesuai khususnya di Kepulauan Riau yakni Batam.

\section{LANDASAN TEORI}

\section{A. Near Field Communication (NFC)}

Near Field Communication (NFC) adalah perangkat komunikasi dengan teknologi berbasis konektivitas nirkabel berbasis RFID (Radio Frequency Identification) yang menggunakan induksi medan magnet untuk memungkinkan komunikasi antar perangkat elektronik dalam jarak yang dekat. Contohnya ponsel yang terintegrasi dengan teknologi NFC, pengguna dapat dengan mudah menyentuhkan ponselnya ke perangkat NFC lain untuk membeli barang, berbagi kartu bisnis dan lainnya. NFC bekerja antara dua perangkat yang berdekatan pada jarak beberapa sentimeter, setelah sambungan telah dibuat dalam hitungan detik informasi dapat dipertukarkan antara dua perangkat, baik menggunakan NFC secara langsung atau melalui teknologi nirkabel.

Teknologi NFC memungkinkan interaksi dua arah sederhana dan aman antara perangkat elektronik, yang memungkinkan konsumen untuk melakukan transaksi contactless, mengakses konten digital, dan menghubungkan perangkat elektronik dengan satu sentuhan. NFC melengkapi 
banyak teknologi nirkabel tingkat konsumen populer, dengan memanfaatkan elemen kunci dalam standar yang ada untuk teknologi kartu contactless (ISO / IEC 14443 A \& B dan JISX 6319-4). NFC dapat kompatibel dengan infrastruktur kartu contactless yang ada dan memungkinkan konsumen untuk memanfaatkan salah satu perangkat di sistem yang berbeda. Memperluas kemampuan teknologi kartu contactless NFC juga memungkinkan perangkat untuk berbagi informasi pada jarak yang kurang dari $4 \mathrm{~cm}$ dengan kecepatan komunikasi maksimal 424 kbps. Pengguna dapat berbagi kartu nama, melakukan transaksi, mengakses informasi dari poster pintar atau memberikan mandat untuk sistem kontrol akses dengan sentuhan sederhana.

\section{B. Elektronik KTP}

KTP berbasis Nomor Induk Kependudukan atau disebut sebagai e-KTP (Elektronik Kartu Tanda Penduduk) menggunakan smart card. e-KTP mengacu pada standar ISO 14443 A/B bekerja dengan baik pada kisaran suhu antara $25^{\circ} \mathrm{C}$ sampai dengan $70^{\circ} \mathrm{C}$ sedangkan kisaran frekuensi operasional 13,56 MHz $+7 \mathrm{KHz}$. E-KTP mempunyai SAM (Secure Access Module) berupa 4 digit UIDs (Uniqe Identifier) dalam range kombinasi 10 digit.

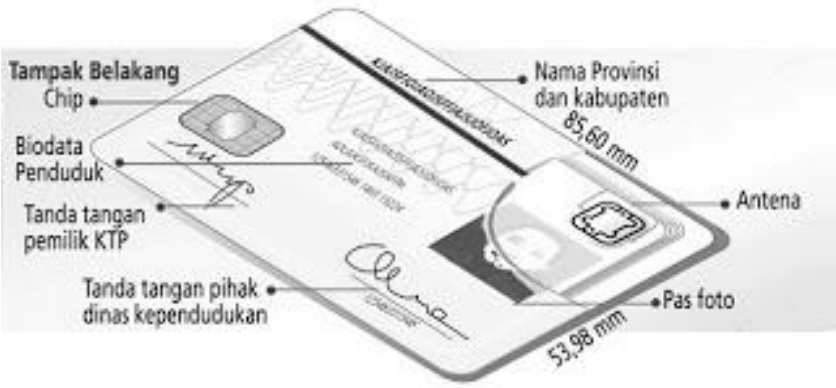

Gbr. 1 Ilustrasi transparant e-KTP [11]

Pada bagian kanan atas terdapat antena dan ada sebuah kotak chip dimana data tentang informasi pengguna KTP disimpan.

\section{METODE PENELITIAN}

Metode dalam penelitian ini menggunakan framework pengembangan software model spiral. Diawali dengan komunikasi dengan pengguna untuk menggali kebutuhan sistem fungsional dan nonfungsional, spesfikasi perangkat keras dan perangkat lunak serta lingkungan sistem yang terlibat. Perencanaan dan pemodelan mendapatkan gambaran sistem secara keseluruhan dengan mendeskripsikan menggunakan Unified Model Langguage (UML).

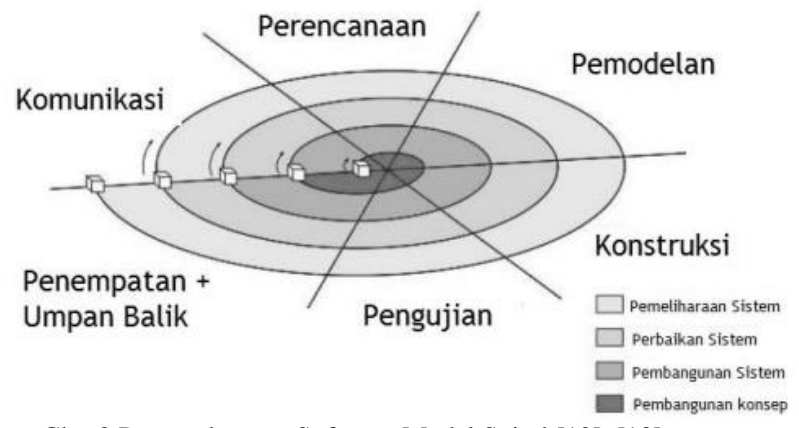

Gbr. 2 Pengembangan Software Model Spiral [12], [13]

Konstruksi dan pengujian melakukan koding dan testing per unit serta integrasi sistem. Penempatan atau implementasi ke sistem yang sebenarnya untuk mendapatkan feedback untuk kemudian dapat dikembangkan kembali pada iterasi selanjutnya. Pada artikel ini akan mengupas penelitian tentang perancangan sistem yang telah dilakukan survei terhadap pengguna jasa penjualan tiket kapal pancong di Batam.

Batam merupakan bagian dari wilayah Kepulauan Riau, sebagian wilayahnya merupakan pulau-pulau kecil. Transportasi yang utama untuk mengunjungi sebagian wilayah di Kepulauan Riau adalah kapal. Saat ini kapal merupakan transportasi yang paling banyak di daerah-daerah hinterland. Salah satu contoh kapal pancung adalah kapal kayu bermesin motor yang bermuatan 14 orang, yang terdiri dari 13 penumpang dan 1 juru kemudi. Pancung merupakan alat transportasi laut yang melayani penyeberangan dari pelabuhan Sekupang - Belakang Padang (PP). Belakang Padang adalah salah satu kecamatan di Kota Batam yang terletak di luar pulau atau daerah hinterland. Menurut Persatuan Pengemudi Motor Sangkut (PPMS) harga tiket untuk sekali perjalanan Rp. 15.000,- dengan jarak tempuh 25 menit dari pelabuhan pancung Sekupang, Batam.

Saat ini terdapat rata-rata sebanyak $200-300$ pengemudi pancung yang bernaung dalam PPMS. Beberapa bertempat di Sekupang, Telaga pungkur dan Belakang Padang dan rata-rata pengemudi / penambang pancung beroperasi dalam tiap harinya dapat mencapai 10-15 kapal pancung dihari biasa, akan tetapi di hari-hari besar atau akhir pekan dapat meningkat sekitar 10-30 kapal pancung yang beroperasi dan jumlah penumpang yang datang mencapai kurang lebih 300 orang.

Kapal pancung atau yang biasa disebut dengan motor sangkut adalah penyedia jasa dalam bertransportasi laut. Selama ini, untuk memesan tiket penumpang masih menggunakan cara manual, dimana para penumpang membeli tiket di loket kemudian membayar langsung ke petugas dan mendapatkan bukti pembelian berupa tiket dan tiket tersebut dipegang oleh masing-masing penumpang selama perjalanan menggunakan kapal pancung sebagai bukti telah membeli tiket sebelumnya. Pengarsipan dalam penjualan tiket pancung masih menggunakan buku, kertas dan alat tulis, hal ini tentu tidak praktis dalam mengolah data. Pada penjualan tiketpun sulit dapat diketahui jumlah penjualan tiket yang terjual. 
Selain itu, para penumpang yang berkunjung dari SekupangBatam-Belakang Padang berbagai macam daerah asal, hingga sulit pula mengetahui jumlah pendatang baru yang berkunjung.

\section{HASIL ANALISA DAN PERANCANGAN}

Setelah melakukan survei dan kebutuhan di lapangan maka disusunlah suatu dokumentasi pengembangan perangkat lunak. Penjabaran teknologi yang dalam pengembangan perangkat lunak setelah dikaji dapat dilihat pada ilustrasi gambar berikut.
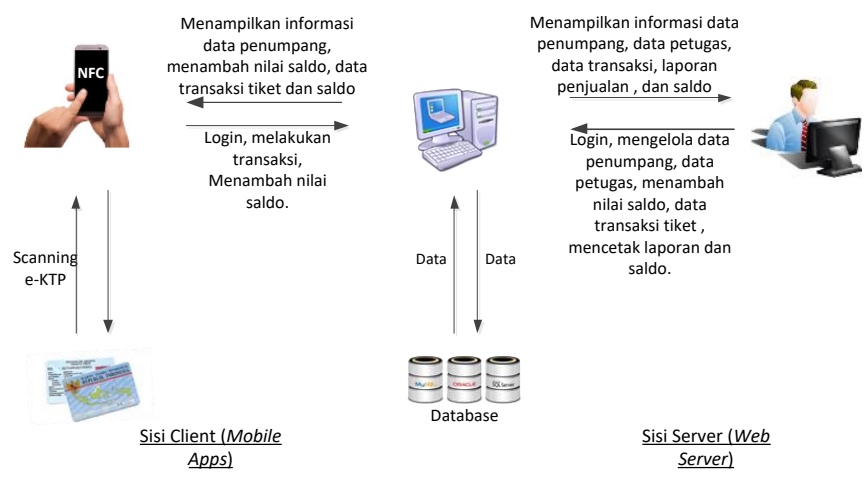

Gbr. 2 Ilustrasi Sistem yang Dikembangkan

Deskripsi umum sistem menjelaskan proses kerja aplikasi penjualan tiket kapal. Prancangan sistem terdiri pada sisi server menggunakan aplikasi web sedangkan sisi client pada perangkat bergerak smartphone android. Aktor yang memiliki hak akses yaitu admin, sedangkan petugas loket dan tiket hak akses pada client perangkat smarthphone. Penggalian kebutuhan fungsional dan non fungsional sistem dijabarkan dalam tabel berikut.

TABEL I

KEBUTUHAN FUNGSIONAL

\begin{tabular}{|c|c|c|}
\hline No & Kode & Fungsional \\
\hline 1 & F-001 & Aplikasi dapat memproses login user \\
\hline 2 & F-002 & $\begin{array}{l}\text { Aplikasi dapat menampilkan informasi } \\
\text { data penumpang, petugas, transaksi } \\
\text { tiket, dan nilai saldo }\end{array}$ \\
\hline 3 & F-003 & $\begin{array}{l}\text { Aplikasi dapat menampilkan status } \\
\text { transaksi tiket }\end{array}$ \\
\hline 4 & F-004 & Aplikasi dapat memproses validasi tiket \\
\hline 5 & F-005 & $\begin{array}{l}\text { Aplikasi dapat memproses transaksi } \\
\text { tiket }\end{array}$ \\
\hline 6 & F-006 & $\begin{array}{l}\text { Aplikasi dapat menambah data } \\
\text { penumpang }\end{array}$ \\
\hline 7 & F-007 & $\begin{array}{l}\text { Aplikasi dapat mengubah data } \\
\text { penumpang }\end{array}$ \\
\hline 8 & F-008 & Aplikasi dapat menambah data petugas \\
\hline 9 & F-009 & Aplikasi dapat mengubah data petugas \\
\hline 10 & F-010 & $\begin{array}{l}\text { Aplikasi dapat menghapus data } \\
\text { penumpang, petugas, transaksi tiket dan } \\
\text { nilai saldo }\end{array}$ \\
\hline 11 & F-011 & $\begin{array}{l}\text { Aplikasi dapat menambah nilai saldo } \\
\text { penumpang }\end{array}$ \\
\hline 12 & F-012 & Aplikasi dapat mencetak laporan \\
\hline
\end{tabular}

\begin{tabular}{|l|l|l|}
\hline \multicolumn{3}{|c|}{ transaksi } \\
\begin{tabular}{|l|l|} 
TABEL III \\
Kebutuhan NON FungSiOnAL
\end{tabular} \\
\hline No & Kode & Non Fungsional \\
\hline 1 & NF-001 & Tampilan aplikasi user friendly \\
\hline 2 & NF-002 & $\begin{array}{l}\text { Aplikasi menggunakan B Bahas } \\
\text { Indonesia }\end{array}$ \\
\hline 3 & NF-003 & $\begin{array}{l}\text { Aplikasi hanya dapat diakses pada } \\
\text { jaringan internet }\end{array}$ \\
\hline
\end{tabular}

Spesifikasi perangkat keras dan perangkat lunak yang digunakan dalam pengembangan aplikasi sebagai berikut.

TABEL IIIII

SPESIFIKASI KEBUTUHAN PERANGKAT KERAS DAN LUNAK

\begin{tabular}{|l|l|}
\hline Perangkat Komputer & Jenis \\
\hline Processor & Intel (R) Core (TM) Duo CPU \\
\hline Memory & 4,00 GB RAM \\
\hline Video Card & Intel \\
\hline Display & 1366 x $768(32$ bit) $(60 \mathrm{~Hz})$ \\
\hline Perangkat Mobile & Jenis \\
\hline Brand & SM-N7505 \\
\hline Processor & Qual Core 1.3 GHz \\
\hline Memory & 16 Gb \\
\hline Connectivy & Bluetooth, WLAN, NFC, 3G \\
\hline Operating System & Android 4.3 \\
\hline
\end{tabular}

Teridiri dari perangkat komputer dan mobile dimana masing-masing spesifikasi tersebut untuk pengembangan sistem dengan memperhatikan lingkungan pengguna. Hasil perancangan use case sistem yang dikembangkan terdapat dua sisi bagian client dan server, dijelaskan dalam gambar berikut.

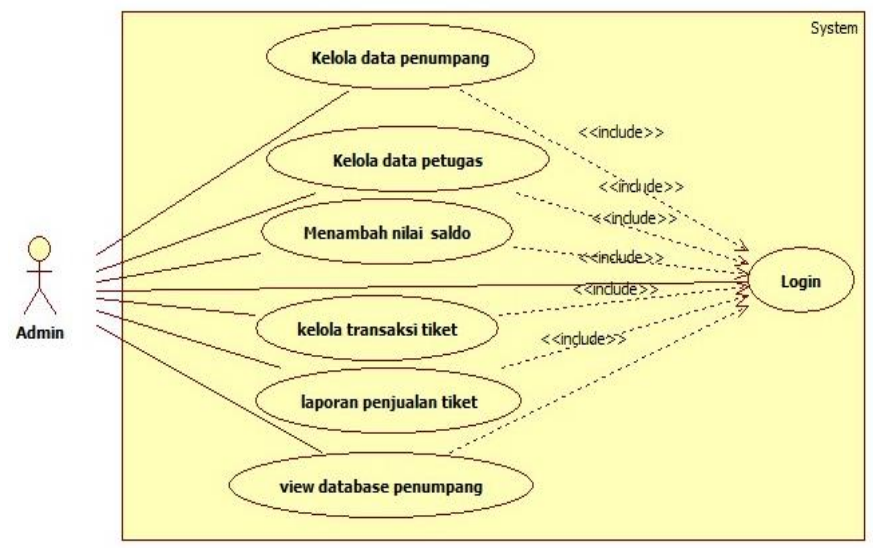

Gbr. 3 Use Case Diagram Server (Aplikasi Web)

Aktor admin yang memiliki use case / interaksi pada sistem dalam aktifitas kelola data penumpang, kelola data petugas, menambah nilai slado, login, kelola transaksi tiket, cetak laporan penjualan tiket, serta view database penumpang. 


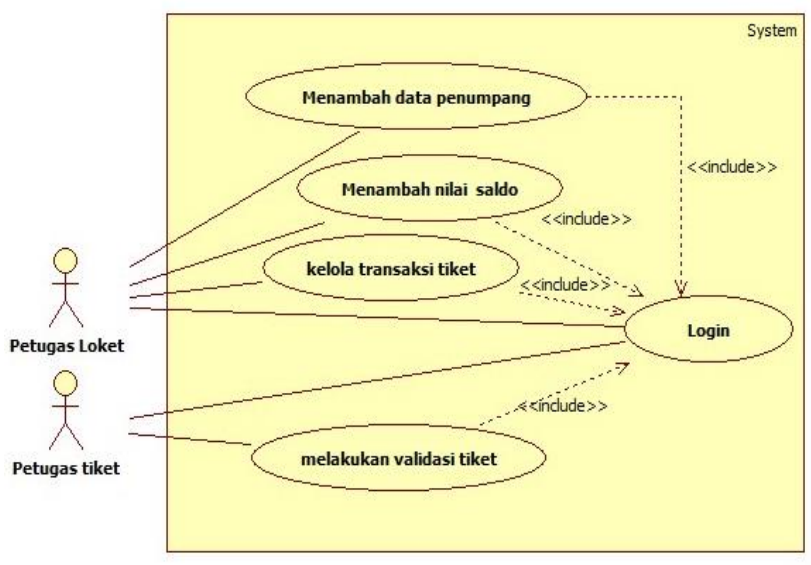

Gbr. 4 Use Case Diagram Client (Perangkat Mobile)

Pada sisi client terdapat dua aktor yaitu petugas loket dan petugas tiket, yang masing-masing memiliki use case / interaksi pada sistem yang berbeda. Pada aktor petugas loket, interaksi dapat menambah data penumpang, login, menambah nilai saldo, kelola transaksi tiket, dan pada petugas tiket memiliki interaksi dalam melakukan validasi tiket serta login. Hasil perancangan database diilustrasikan pada ER-Diagram sebagai berikut.

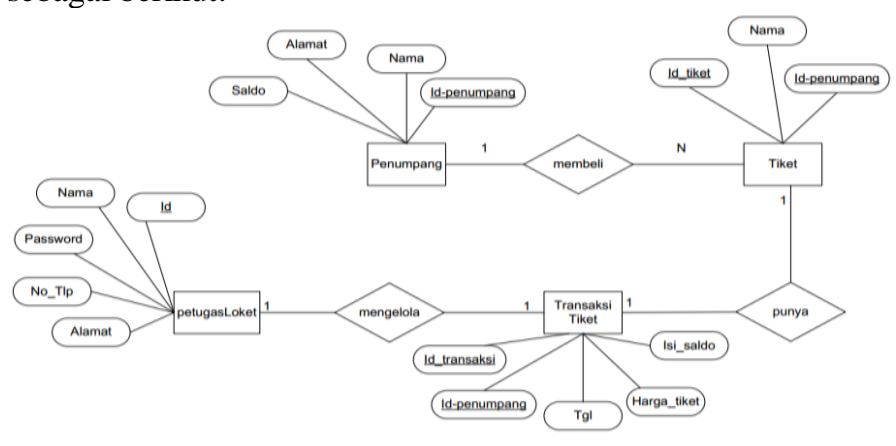

Gbr. 5 Entity Relation Diagram (ERD)

Terdapat empat entitas dan tiga relasi. Entitas tersebut diantaranya penumpang, tiket, petugas tiket dan transaksi tiket. Entitas penumpang memiliki atribut nama_penumpang, id_penumpang, alamat_penumpang dan saldo. Entitas tiket memiliki atribut id_tiket, nama, dan id_penumpang. Entitas transaksi tiket memiliki atribut id_transaksi, id_penumpang, tanggal_transaksi, harga_tiket dan isi_saldo. Entitas petugas loket memiliki id_petugas, nama_petugas, password, no_tlpn dan alamat_petugas. Entitas penumpang dan tiket memiliki relasi membeli $(1: \mathrm{N})$. Entitas tiket dan transaksi tiket memiliki relasi punya (1:1). Entitas petugas loket dan transaksi tiket memiliki relasi mengelola $(1: 1)$.

Hasil perancangan antar muka dalam pengembangan sistem pada sisi client perangkat mobile dan sisi server pada aplikasi web sesuai dengan use case diantaranya diilustrasikan pada gambar berikut.

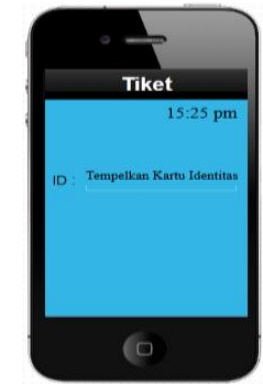

tap/validasi ktp pada perangkat nfc

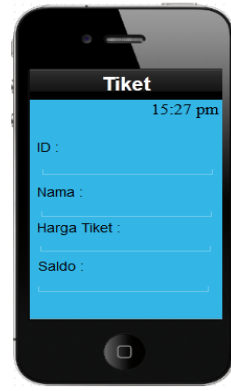

data transaksi

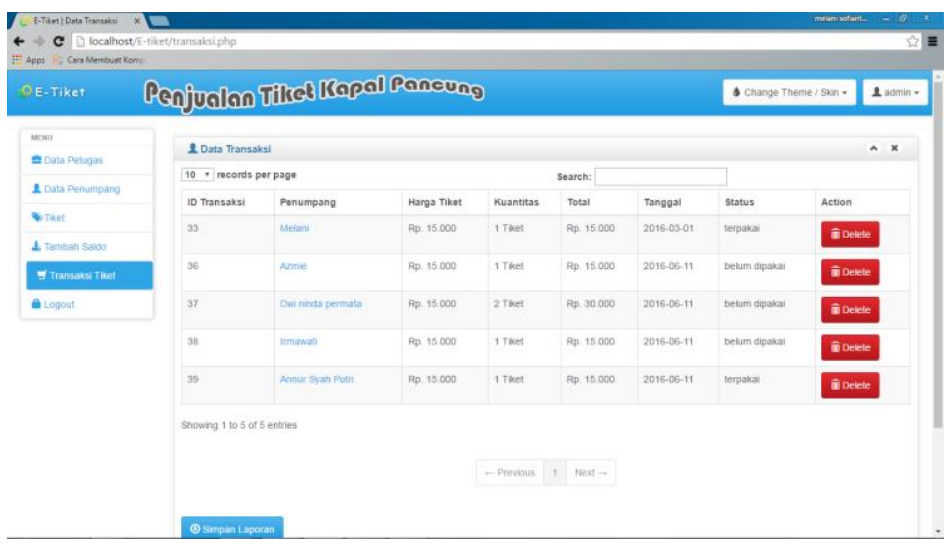

Gbr. 6 Hasil Rancang Antarmuka Sisi Client dan Sisi Server

Hasil perancangan antarmuka sisi client dan server yang diperoleh merupakan hasil kebutuhan pengguna dengan melakukan validasi hasil survei dari prototype pengembangan sistem.

\section{PENUTUP}

Berdasarkan hasil perancangan sistem dapat disimpulkan sebagai berikut.

1. KTP elektronik saat ini telah mendukung perangkat NFC, chip menyimpan data informasi pengguna sehingga dapat digunakan dalam aktifitas transaksi.

2. Pengembangan dilakukan pada sisi client perangkat mobile dengan pemilihan sistem operasi android dan sisi server berupa aplikasi web untuk menyimpan data transaksi penjualan tiket kapal.

3. Hasil penggalian kebutuhan fungsional terdapat 12 fungsional dan 3 non fungsional pada pengembangan aplikasi penjualan tiket kapal.

4. Terdapat 3 aktor diantaranya petugas loket, petugas tiket dan admin yang terlibat dalam aplikasi penjualan tiket kapal.

5. Perancangan database menggunakan Entity Relation Diagram (ERD) dimana terdapat empat entitas dan tiga relasi dalam penjualan tiket kapal. 


\section{UCAPAN TERIMA KASIH}

Peneliti mengucapkan terimakasih kepada Ristek Dikti dan P3M Polibatam serta Melani, dkk. D3 Teknik Informatika Politeknik Negeri Batam yang telah membantu dalam melakukan survei kebutuhan pengguna dan pengembangan aplikasi dalam penelitian ini.

\section{REFERENSI}

[1] F. Richardo, Aplikasi Mesin Penjualan Tiket Bus Trans Batam, Jurusan Teknik Informatika Politeknik Negeri Batam.

[2] Supriyono, H., Setyaningrum, R. (2012). Rancang Bangun Prototipe eTicket BRT (Bus Rapid Transit) Trans Semarang Menggunakan Teknologi Near Field Communication (NFC) Sebagai Upaya Optimalisasi Pelayanan Transportasi.

[3] Laman Katadata.co.id tersedia di http://databoks.katadata.co.id/datapublish/2016/08/08/penggunasmartphone-di-indonesia-2016-2019.

[4] Ariansyah, K. (2012) Studi kesiapan penyelenggaraan layanan Nea Field Communication (NFC) komersial di Indonesia. Buletin Pos dan Telekomunikasi Volume 10 No.3

[5] M. E., "NFC Timing Restrictions," Nfcsec, August 2011.

[6] H. Du, "NFC Technology: Today and Tomorrow," International Journal of Future Computer and Communication, vol. 2, no. 4, pp. 351354, 2013.

[7] Supriyono, S. H. and R., Rancang Bangun Prototipe E-Ticket BRT (Bus Rapid Transit) Trans Semarang Menggunakan Teknologi Near Field Communication (NFC) sebagai Upaya Optimalisasi Pelayanan Transportasi, 2012

[8] A. D., "How the New Google Wallet Mobile Payment System Works," Time Magazine Techland, May 2011.

[9] B. Alessandra, L. Walter and P. Federica, "NFC Smart Tourist Card: Combining Mobile and Contactless Technologies towards a Smart Tourist Experience," in WETICE Conference (WETICE), 2014 IEEE 23rd International, 2014.
[10] T. J., "The Future NFC, From Mobile Wallets to Angry Birds," Read Write Web, 14 June 2011

[11] R. Rahmandaru., NFC Hacking. Tersedia dia http://robzlabz.blogspot.co.id/2012/07/nfc-hacking.html

[12] McLeod Jr. P, GP Schell. 2007. Sistem Informasi Manajemen. Edisi ke-9. Yuliyanto dan Heri, penerjemah: Jakarta: Indeks. Terjemahan dari: Management Information System, Edisi ke-8. Pearson Prentice Hall, Inc.

[13] Pressman RS. 1997. Rekayasa Perangkat Lunak. Edisi ke-2. LN Harnaningrum, penerjemah: Yogyakarta: Andi. Terjemahan dari: Software Engineering, a Practitioner's Approach, Edisi ke-4. McGrawHill Companies, Inc

[14] Kurniawan, D. E., \& Surur, M. N. (2016). Perancangan Sistem Pengamanan Sepeda Motor Menggunakan Mikrokontroler Raspberry Pi dan Smartphone Android. Jurnal Komputer Terapan, 2(2), 93-104.

[15] Kurniawan, D. E., \& Fajrianto, R. (2017, August). SISTEM PEMANTAU KONEKSI INTERNET MENGGUNAKAN SISTEM INFORMASI GEOGRAFIS DAN SMS GATEWAY. In SISITI Seminar Ilmiah Sistem Informasi dan Teknologi Informasi (Vol. 5, No. 1).

[16] Kurniawan, D. E., \& Surur, M. N. (2017). Sistem Pengaman Sepeda Motor Berbasis Perangkat Bergerak dengan Notifikasi dan Kendali Mesin. Jurnal Sistem Informasi, 9(1).

[17] Kurniawan, D. E. (2017). PUSH NOTIFICATION SYSTEM PADA PROTOTYPE KENDALI LISTRIK RUMAH. CESS (Journal of Computer Engineering, System and Science), 2(2), 89-92.

[18] Kurniawan, D. E., \& Fani, S. (2017). PERANCANGAN SISTEM KAMERA PENGAWAS BERBASIS PERANGKAT BERGERAK MENGGUNAKAN RASPBERRY PI. Jurnal Ilmiah Teknologi Informasi Terapan, 3(2)

[19] Kurniawan, D. E. (2017). SIMULASI PERHITUNGAN TARIF PADA PEMANDU WISATA BERBASIS PERANGKAT BERGERAK CESS (Journal of Computer Engineering, System and Science), 2(1), 12-16. 